\title{
MJN THEN AND NOW: THE EVOLUTION OF THE IMAGE OF NURSING AND NURSES IN MALAY SOCIETY (1957-2018)
}

\author{
Salilah Saidun*, Elmira Akhmetova \\ ${ }^{1,2}$ Department of History and Civilization, Kuliyyah of Islamic Revealed Knowledge and Human Sciences, \\ International Islamic University Malaysia
}

*Corresponding Author'sEmail: salilah.saidun@live.iium.edu.my;s_salilah@yahoo.com

\begin{abstract}
Background: The public image of nursing and nurses evolves from time to time and varies in different societies around the world. Although the issue received scholarly attention, past literary works on the issue in Malay society in Malaysia is scarce. This paper aims to bridge this gap by describing the changes in the public image of nursing and nurses in Malay society from 1957 to 2017. Methods: In this qualitative study, thematic analysis of newspaper reports and interviews transcripts involving senior and retired nurses in four selected healthcare institutions in Peninsular Malaysia - who were identified through purposive and snowball sampling - were conducted. Results: The negative image of nursing as a disreputable work has improved and is now seen as a noble and rewarding profession. However, the evolution of the public image of nurses is a mixed phenomenon where nurses are now perceived to have improved intellectually but have deteriorated in terms of humanity. Conclusion: The study reveals that the image of nursing and nurses in Malaysia had evolved, with the improvement of certain aspects and deterioration in others. As the image evolves in line with the dynamics of nursing and the dynamics of the society, nurses ought to tailor the advocacy effort to improve the representation of nursing and nurses to suit the circumstances from time to time.
\end{abstract}

Keywords: Perception; Public Image; Nursing; Nurse; Malay; Malaysia

\section{INTRODUCTION}

Historically, nursing started as a voluntary service delivered by the monastic communities while modern nursing as a professional service was pioneered by Florence Nightingale's trained ladies during the Crimean War (Roux \& Halstead, 2017). As the profession grew, the public image of nursing and nurses changed from time to time throughout the world. Image is "the way a person appears to others, or in the case of a profession, the way that profession appears to other disciplines and to the general public" (Finkelman \& Kenner, 2010). In this article, nursing refers to the profession while nurses refer to the trained personnel who provide services in nursing.

The public image of nursing and nurses affects the profession, personnel and service recipients in multiple dimensions. It may influence human resource management (recruitment and retention) and resource allotment. Public image may also impact nurses' psychology and performance. All these then determine the quality of service delivery (Kalisch \& Kalisch, 1983). Hence, knowledge of the topic would illuminate and assist an understanding of various nursing-related events and phenomena taking place during the specific period.

\section{Literature Review}

The issue of the public image of nursing and nurses receives great attention in the academic world. Due to the plethora of literary works on the issue, this section summarises the findings of past literary works, based location and period.

\section{Media Portrayal}

In the United Kingdom (UK), although there were observable changes in the public image of nursing in the media-from a high-status working-with-doctors serious job in the 1930s to a romantic lower-status working-fordoctors job starting in the $1960 \mathrm{~s}$ - the image of nursing as women's work has been consistent throughout the period (Hallam, 1998). In the United States of America 
(USA), the predominant image of nurses in media evolved from angelic (mid-nineteenth century to early twentieth century) to assistive (early twentieth century), heroic (early to mid-twentieth century), motherly (midtwentieth century), sexy (mid-twentieth century to late twentieth century), and careerist (late twentieth century) (Kalisch \& Kalisch, 1983). Many Western movies in the twentieth century commonly project nurses as angelic, heroic and sexy while recent films represent nurses as professionals (Stanley, 2008).

In the first decade of the twenty-first century, positive impressions of nursing (in American literature) as an employment opportunity that provides job security and travel opportunities were also reported along with the decreasing prevalence in the perception of femininity of nursing, sexual objectification of nurses, inferiority to medical doctors, and association of nurses with bossy and stern characters (Jinks \& Bradley, 2004). At the same time, many websites depict positive image of nurses with high intellect, accountability, competency, commitment and respect, although the number of websites portraying the positive image decreased between 2001 and 2004 (Kalisch, Begeny \& Neumann, 2007).

In the second decade of the twenty-first century, nurses as sex objects, incompetent serious women and skilled personnel are among the images seen on the internet (Kelly et al., 2012). Despite the professionallooking depiction of nurses engaging in consoling patients and documentation, there is no image of nurses conducting clinical procedure or scientific research (Koo \& Lin, 2016).

\section{General Perception}

Studies in Finland (Manninen, 1998), the USA (Hemsley-brown \& Foskett, 1999), and the UK (Hudson, 1993; Jinks \& Bradley, 2004; Phillips, 1993; Robinson, 1989; While \& Blackman, 1998) in the 1980s and 1990s reported that nursing was seen as a low-status underpaid job, subservient and inferior to (predominantly male) doctors, which focused on caring rather than curing by doing low-skilled, low-technological, and dirty manual routine domestic works that do not require high achievements in academic nor high cognitive functions. Studies in the UK include 'job insecurity' in the lists of negative perceptions towards nursing, while on the positive side, nursing was viewed as a caring profession with career progression opportunities, consistent with the female gender roles, status, and expectations to be obedient wives and caring mothers (Hudson, 1993;
Phillips, 1993; While \& Blackman, 1998). In Canada, nursing is seen as altruistic and caring but involves a routine of mindless menial tasks (Day et al., 1995).

In the twenty-first century, studies in India (Patidar et. al., 2011), Turkey (Başkale \& Serçekuş, 2015), Bahrain (Eman et al., 2012), Belgium (Milisen et al., 2010), Canada (Grainger et al., 2006), the USA (Geigerbrown et al., 2004), and the UK (Moore, 2001) revealed similar perceptions compared to the studies in the $1980 \mathrm{~s}$ and 1990s. In Saudi Arabia, nursing was negatively linked to immorality and disregard toward gender segregation (Mebrouk, 2008). In Kuwait, South Africa, and Bahrain, nursing is highly regarded as a respected profession vital to the society which involves advanced technology and high mental capability (Al-Kandari \& Lew, 2005; Chauke, Wal \& Botha, 2015; Tawash \& Cowman, 2015). Chong (2007) reported that nursing students in Malaysia perceived nursing as a low-status, low-paid, servant-like women's job with limited advancement opportunity. It is also perceived as a secured caring profession which facilitates the sick with their basic daily needs, require tertiary education, and allows one to work with a certain level of autonomy. They also viewed nurses as feminine, gentle, compassionate, patient, and have a good level of physical and emotional strength (Chong, 2007). A systematic review of the literature between 2010 and 2015 suggest that there is a variant perception towards nursing. The public perception towards nursing is generally positive, while in the media, it is still negative (Girvin et al., 2016). In Indonesia, nurses view nursing as a profession with Islamic culture mainly involves in comforting patients and assisting doctors although nurses play a variety of roles including caregiving, decision making, advocating, and teaching (Gunawan et al., 2018).

In general, despite geographical differences, the public image of nursing and nurses have changed towards the positive spectrum over time, whereas some negative stereotypes also remain. The variances of perceptions towards nursing may be due to cultural traditions related to gender roles, culture related to caring for the sick, and norms related to domestic tasks.

Unlike the literature on such topic elsewhere globally, there is a gap in the literature on this issue in Malaysia as there is only one study by Chong (2007). This paper aims to illustrate the evolution of the image of nursing and nurses in the Malay society in Peninsular Malaysia within the six decades of the post-independence era. 


\section{METHODOLOGY}

The study is a part of the larger study on the history of nursing in Malaysia which took place between January 2017 and March 2018. In this study, a narrative inquiry and library research of newspaper reports are conducted to gain insight into the topic. The method is suitable for this study because there is a lack of written materials on the subject which would otherwise allow a systematic review of the literature. The information obtained from the two sources may corroborate each other. In order to allow triangulation to include different types and locations of healthcare institutions that serve a high percentage of Malay patients, four institutions were selected for the study:

1. Ministry of Health Malaysia (MOH), the main public healthcare provider

2. Ministry of Defense Malaysia (MOD), the second-largest public healthcare provider

3. Hospital University Science Malaysia (Hospital USM), a university hospital

4. Hospital Pusrawi Sdn Bhd (Pusrawi), a private healthcare provider

The study is limited to the public image in Peninsular Malaysia due to the geographical limitations of the researchers who are based in Peninsular Malaysia. The image of nursing and nurses varies in different communities. While researching on the issue in different communities in this multiracial country is interesting, it would require greater resource and lengthy discussion. In addition, there is an apparent difference in the involvement of the Malays in nursing during the early post-independence Malaysia (Berita Harian, 1966a) compared to the recent time (The Star, 2005) which suggest the evolved image. Thus, the scope is further focused in the Malay society who are the majority population in Peninsular Malaysia and are Muslims as defined by the constitution.

The inclusion and exclusion criteria of the potential participants of the study are listed as follows:

\section{Inclusion Criteria}

I. Senior or retired Malay nurses who had experience or are still practising in Malaysia

ii. Underwent nursing training before the middle of the 1990s (at least two decades of experience)

iii. Has the ability to speak in Malay or English

\section{Exclusion criteria}

i. Does not have any problems with cognitive function

ii. Does not have any debilitating illness

Purposeful sampling and snowball sampling techniques were used to identify potential participants. In purposeful sampling, the principal investigator (PI) identified senior nurses in the institution and approached them. The participants were then welcomed to nominate other colleagues or retired colleagues who fulfil the above criteria for the study which allowed the identification of other potential participants through snowball sampling. The identified potential participants were approached, briefed regarding the research, and invited to participate. If they agreed, a meeting was organized. Once the informed consent was obtained, an audio-recorded faceto-face unstructured interview was conducted either at the participant's home, workplace or a public meeting place, depending on her preference. No one else was present during the interviews, which lasted between twenty minutes to two hours, without any repeat interview. The PIs provided the questions and prompts, which were revised and improved based on the participants' feedback. Most of the interviews were conducted in Malay and the text excerpts are translated to English in this article. Nineteen senior and retired nurses participated when the PI could not identify new emerging codes from the data and thus, data saturation was considered to be achieved. Two potential participants refused to participate (senior nurses) due to their tight work schedules, a few potential participants were unable to be contacted and none of the participants withdrew from the study.

Transcription was conducted within 48 hours and returned to participants for verification. Anonymization by codes was done by assigning an alphabet which identifies the site $(\mathrm{H}$ for $\mathrm{MOH}, \mathrm{D}$ for $\mathrm{MOD}, \mathrm{U}$ for Hospital USM, and P for Pusrawi) followed by the code number of the participant. Data entry, management, security, and coding were done by the PI, using Qiqqa. The themes were not pre-determined but emerged from the data.

All participants are female because nursing has been a women's sphere before men started appearing in nursing only by the turn of the new century. Eight participants started practising in the 1970s, seven participants started in the $1980 \mathrm{~s}$, and four participants have been practising since the early 1990s. Collectively, 
at least one participant of the study has experience practising in each state in Peninsular Malaysia, except Perlis, the smallest state in the northernmost region, bordering Thailand. This is due to the difficulty to find a potential subject with the experience of practising in Perlis who is willing to participate and able to be reached by the investigator.

Since the study involves human participants, ethical clearance was obtained from the first three institutions. Pusrawi does not have its own ethics committee, but the ethical clearance by the other three institutions is sufficient. Participants did not receive any monetary or other direct benefits for participating in the study. In order to protect the identity of the participants as stipulated by all three ethics committee, the participants are anonymized by codes.

\section{RESULTS}

The participants noted that the public perception towards nursing and nurses has never been unanimous. Although individual perceptions differ, the general perception of the society has been prominent. Except where specifically stated in the following sections, the participants reckoned that the general perception has been similar across different geographical locations.

"That [the perception] depends on each individual".

"I think it [the perception] was similar overall in Malaysia". (H03)

\section{Nursing: From a 'Dirty' Low-Ranked Women-only Job to a Highly-Qualified Women-Dominated Profession}

Generally, the image of nursing in the eyes of the Malays was negative during the early decades of Malaysia's independence, although the participants also cited that a proportion of society saw nursing as a noble profession. Tan Sri Md Khir Johari, the Ministry of Education in 1965 stressed the nobility of nursing when commenting on the polemical issue regarding inappropriate behaviours (which will be discussed in the next section) of nurses at that time (Berita Harian, 1965a).

"The society has always accepted nursing as a noble job". (H01)

"Maybe they see nursing as a low[-ranked] profession. I don't know why, but there were not many who were interested to join nursing".(U04)

The overall negative image of nursing was due to multiple reasons. Firstly, the participants reported that nursing was generally perceived as a 'dirty' work because of the nature of work in dealing with dirty bodily fluids and excretions. However, the perception was more predominant among the Malay majority compared to the others (Participants P05 and U05). The disinterest of the Malays was prominent that only ten per cent of the new nurse students enrolled in 1963 were Malays even though Malays were given a priority (Ratnamala, 1963). By 1966, of the total three thousand registered nurses in Malaysia, only 324 Malay nurses (Berita Harian, 1966a). The dirty-work image was not merely a laymen perception but nurses felt the same way to the extent that of Taiping Hospital nurses went on a strike protesting the 'dirty' and 'low' works involving cleaning bedpans (Berita Harian, 1959a). Secondly, the perception was also related to the low salaries that nurses received (Berita Harian, 1964a). Due to the low image, some nurses were ashamed to introduce themselves as nurses (Berita Harian, 1957a).

"People see nursing at that time as a dirty work. That's (the perception) for the Malays. For the Chinese, it was different. My neighbours were all Chinese... All my neighbours were like, "Oh we're so happy that you will become a nurse, very good, you go, we are very happy'.(P05)

The perception towards the femininity of nursing is evident in Malaysia with the absence of male nurses before the new millennium. Although men have started joining the nursing workforce, women are still the dominant gender in nursing.

"Nursing is a diverse discipline monopolized by women since many years ago. Male involvement is seen only in the past five years or so". (P03)

The review of newspaper reports on nursing and nurses unfolded other images of nursing in the 1950s and 1960s that none of the participants mentioned as they have not started practicing until the 1970s. Nursing was portrayed as a profession with great responsibilities (Berita Harian, 1960a, 1968a). Newspaper articles commonly reported the work-related risks in nursing including workplace bullying, physical assaults and sexual harassment (Berita Harian, 1959b, 1959c, 1962a, 1966b). The possibility of being posted to serve rural areas was another unfavourable feature that was voiced 
by nurses in the newspapers (Berita Harian, 1957b, 1957c, 1963a, 1968a). On the positive side, nursing opened the opportunity for women to undergo training in Australia, the United Kingdom, Hong Kong, and Thailand (Berita Harian, 1957d, 1960b, 1969).

The differences in perception between lay public and other healthcare workers towards nursing are noted as well. Despite that, nurses still feel that their department has always been given less priority compared to other departments in the institution.

"The doctors understand our work more than the lay public".(U02)

"Usually, the nursing departments are generally among the last department to be given attention but when any work is required, the nursing departments will be among the first to be given the task". (U01)

Over the years, the image of nursing underwent vast transformations. Firstly, the image of managing dirty bodily fluids and excretion has been surpassed by the nobility of nursing and helping the sick, which is beneficial for the family members of nurses and the society at large. The change in perception is associated with an increased encounter with the hospital. Besides that, a nurse could become a nurse educator by teaching the future generation of nurses, which is considered another noble act by the society (Dain, 2005; mStar Online, 2010a; Yazid, 2010).

"Previously, there were not many who are interested to join nursing, they are more interested in becoming school teachers. Now, maybe people have opened their eyes. When we become nurses, we could help our family members too, and not just that, we could also become a teacher by teaching the future nurse generation. So, we could see the evolution (of perception)".(U04)

The image of nursing has shifted from a low-ranked profession to one that requires high qualifications, has greater authority, provides a good monetary reward, and offers promising career progression in Malaysia or overseas (Kamaruzaman, 2016; mStar Online, 2010b, 2016; Yazid, 2010).

"Now it is because of the career opportunity in nursing. Nurses could further their studies to higher levels or undertake post-basic training in various subspecialities. We have our authority and we are the backbone of a hospital. Without doctors, a hospital could continue operating but without nurses, the hospital will not be able to operate". (U02)
"There is a change. Now people see that [working as] nurses is good because they could not run from materialism, they know that these nurses are well paid. Previously, between nursing and teaching, people prefer to become teachers. Now, (the two is) equivalent. Now, it is not easy to get a place in nursing school instead". (U05)

The improvement of the nursing profession has attracted higher achievers to join nursing, demolishing the image of nurses being underachievers in academic. Unlike the situation during the early period of independence where there was a shortage of nurses, currently, newly qualified nurses are having difficulty securing jobs (Utusan Online, 2018). Despite observing improvements of the image, the participants cited that the status of nursing has not been adequately acknowledged compared to the situation in developed countries where they receive greater authority and respect.

"At overseas, nurses are more respected. So, doctors who are familiar with the overseas system respect nurses more but some have greater egos. At overseas, the doctors consult the nurses before discharging the patients. In the ward, nurses have more authority, and this is different here. Sometimes, some of our nurses just wait for the doctors' instruction when actually we could act on our own in certain things". (U02)

\section{Nursing: From Western Colonial Tradition to Islamic Heritage}

Among the Malay majority populace, nursing was associated with the Western colonial profession because it was introduced by the British during the colonial rule.

"Previously, we followed the colonial system because there were many nurses who came from [or were trained] there". (U01)

The image of nursing in the eyes of the Malaymajority society evolves with the discovery of the Islamic roots of nursing. This newly found historical knowledge has redefined its image as a profession brought by the colonial government to the Islamic heritage of the Companions of the Prophet of Islam.

"Because now we are more exposed. Previously, we were exposed to Florence Nightingale, then we started knowing about the first school of nursing that was built near Masjid Al-Nabawi [in Madinah, Saudi Arabia] where Rufaydah [a female Companian] trained Muslim women to treat wounded soldiers in the war at that time". (H02) 


\section{Nurses: Previously Negatively Seen as more Sociable Women Compared to Now}

During the colonial rule, the Western culture of socialising infiltrated many British-led systems including healthcare. The foreign culture led to a negative perception towards nurses as sociable women as they were in close contact with men (personnel and patients) frequently, commonly participated in parties and commonly wear dresses that do not conform to the Malay modest dress code.

"Previously, people see nurses as those who were doing messy work and being sociable... Because nurses were always in close contact with doctors... Moreover, nurses were wearing (knee-length) skirts. Sometimes, some nurses were with doctors in seclusion and some were caught”. (U01)

"They said nurses are sociable. Too sociable... Because annually, when I was still a student nurse, we would organize annual dinner, so during the dinner, the nurses were mixing around with all these things". (P05)

The participants noted differences in perception among those who live in urban areas compared to the rural areas.

"When I was in training in Kuala Lumpur, you know how those in KL were at that time. They prefer to wear such clothes [that do not conform to the traditional Malay dress code]". (U05)

"In Malay-predominant Terengganu where traditional customs and religion is more upheld, there was disagreement [with how nurses dressed]". (H01)

There were multiple reports in the newspapers regarding the discomfort that the Malay community felt with the social lifestyles of nurses, including wearing inappropriate dresses (at work and outside of work), having illicit relationships and organising parties that served alcohol and involved dances which contradicted the Malay custom (Berita Harian, 1958a, 1958b, 1963b, 1964b, 1965a, 1965b, 1966c, 1968b, 1970).

\section{Nurses: Previously Seen as Underachievers in Academics Compared to Now}

Nurses were also viewed as academic underachievers, compared to other preferred female-dominated professions, such as teachers, which were highly preferred (Mariam, 1959).
"They looked down on us... because they perceived that we are not clever enough". (U05)

"Why do you want to become a nurse, why not a teacher?". (H04)

To improve the number of Malay nurses, the assistant nurse posts were created which required lower entry qualification. However, the better qualification of the non-Malay applicants lowered the chances of Malay applicants being accepted (Mohamad, 1970).

Currently, the improvement of the nursing profession has attracted high achievers to join nursing, thus demolishing image of nurses as being underachievers.

"I had interviewed one candidate who obtained $10 \mathrm{~A}$ (in the Malaysia Education Certificate)... 'You obtained $10 \mathrm{~A}$, you could do medicine and become a doctor'. (She replied), "No, I want to be a nurse". (P06)

\section{Nurses: Previously Seen as More Humane Compared to Now}

Despite the above stated negative image of nurses, they were also seen by others as compassionate and dedicated, especially by those who have received nursing care.

"Before this, nurses were closer to the patients because we did everything ourselves. Now, we have technology... That is what we always hear anywhere we go". (P02)

The newspaper articles revealed a different story. In the 1950s and 1960s, nurses were commonly described as fierce, rough, and rude (Berita Harian, 1965c, 1966d, 1967a, 1967b, 1968c, 1968d). The image started changing after the Ministry of Health called nursing to provide more friendly service since the mid-1960s (Berita Harian, 1959d, 1961a, 1961b, 1962b, 1962c). None of the participants started practising in the 1950s, which may explain why this was not mentioned by any of the participants.

As the nursing force expended, the general humanity of nurses is observed to deteriorate. Nurses are now seen to be becoming more aloof. The widespread use of social media viral cases of rude nurses or nurses who seemed like they were doing non-work-related things during their shifts (Abdullah, 2015; Hasli, 2014). On the other hand, the photos of nurses who continued working despite being sick were also viral and described as altruism (Sulaiman, 2019). 
"The current generation is 'busy', even while attending patients, they still have to keep checking their mobile phones. Previously, we did not have these technologies ... Now, I don't know, it is not only nurses who behave as such, but everyone in this generation". (U03)

\section{DISCUSSION}

The image of nursing and nurses in Peninsular Malaysia vary between geographical locations (urban versus rural), racial groups (Malay versus non-Malay), and individuals. In general, the image of nursing improved over time as it transformed from a disreputable work to a noble rewarding profession. This is consistent with other studies in the literature as highlighted above despite the geographical, religious, and cultural differences. On the contrary, the evolution of the image of nurses illustrates changes in different dimensions where nurses are seen to have higher intellectual capacity but lower humanity compared to the previous generation. However, the issue is not considered exclusive to nurses but is associated with the whole current generation. Comparing the findings with that of reported by Chong (2007), the similarities of the current society's perception includes the helping nature of the profession, the high qualification required, and having a certain level of autonomy. The participants in Chong's study (2007) perceived the contrary when it comes to the status, monetary reward, and advancement opportunity. The findings in the current study suggest the reducing level of humane touch, contrary to Chong's report (2007). These variances in perceptions may be due to the contrasting nature of the present study where the participants were asked to compare the image in the previous era and the present, and not comparing nursing with other professions in the present time. Comparing the result with other Muslim-majority countries like Indonesia, Kuwait and Bahrain (Al-Kandari \& Lew, 2005; Gunawan et al., 2018), the present study suggests that the current image on nursing is highly regarded as a noble profession which requires a considerable mental capability. The negative image related to immorality and disregard toward gender segregation like in Saudi Arabia (Mebrouk, 2008) is not evident in Malaysia at present, although nurses had been perceived as sociable women in the past. The variances in perceptions towards nursing may be due to cultural traditions instead of religion.

The current findings illustrate several factors which influence the evolution of the image of nursing over time. Factors related to nursing include improvement of including salary scheme, increasing nurse qualification, improvement of advancement prospect, and inclusion of male members in the nursing force. Technological changes influence the nurse-patient relationship and, in turn, the public image of nurses. As modern healthcare services expand and more Malaysians receive the services, their perception towards nursing and nurses changed. The transformation of the society's awareness and knowledge related to the two issues also fuelled the evolution. For the Malays, this includes the new knowledge of Islamic nursing heritage.

\section{CONCLUSION}

The study reveals that the image of nursing and nurses in Malaysia had evolved with the improvement of image on certain aspects and deterioration of that in other aspects. The findings on the image nursing and nurses echoed many of the findings in previous studies. The evolution of the image is driven by the dynamics of nursing and the dynamics of society. Hence, the effort of advocating for the proper representation of the image of nursing and nurses ought to be continuous and appropriate with the evolving circumstances in nursing and society.

\section{Limitation and Recommendation}

The scope of the study is limited to Peninsular Malaysia and may not reflect the image in East Malaysia. Although none of the participants is from Perlis, the findings may likely reveal similar results because the culture and ethnic composition do not differ much from other states in Peninsular Malaysia. The study presents the evolution of the image of nursing and nurses from the narratives of senior and retired nurses, which is based on their perception and memory of what happened in the past decades. Although such account may not be accurate to represent the general perception of Malaysians, it is still significant in providing valuable insight on the issue in the absence of other more concrete evidence (such cross-sectional study on the issue in different decades). Hence, future studies are recommended to include other forms of media (novels, televisions, movies, social media, art and literature) and non-nurse participants (such as lay public or family members of nurses) from various racial groups to explore deeper on the issue in Malaysia.

\section{Conflict of Interests}

The authors declare that they have no conflict of interest. 


\section{ACKNOWLEDGEMENT}

We would like to thank the Director General of Health Malaysia and Director of the Hospital Universiti Sains Malaysia (USM) for their permission to publish this article. We thank the following institutions or granting the permission to the investigator to access its space, assets and staff during the process of conducting the research. Special thanks also go to the following individuals who have relentlessly assisted us in making the research work successful.

\section{Ministry of Health Malaysia}

a. Director General of Health

b. Deputy Director General of Health (Research and Technical Support)

c. Deputy Director General of Health (Medical)

d. Director of the National Institute of Health Secretariat

e. Director of Nursing

f. Principal Assistant Director of Nursing (Research and Development)

g. Medical Research and Ethics Committee, Ministry of Health [NMRR-16-2364-33183]

h. All employees who assisted in the study

\section{Ministry of Defence}

a. Chief of the Defence Force

b. Chief of the Army

c. Director-General of Health Services

d. Director General, Army Religious Corps (KAGAT)

e. Director General, Science Technology Research Institute for Defence (STRIDE)

f. Ethics Committee, Tuanku Mizan Armed Forces Hospital [HATTM/EK/17-02]

g. All employees who assisted in the study

\section{Hospital Universiti Sains Malaysia}

a. Director of the Hospital Universiti Sains Malaysia(USM), Kubang Kerian, Kelantan.

b. Senior Assistant Director (Nursing)

c. Human Research Ethics Committee, Hospital USM [USM/JEPeM/17020134]

d. All employees who assisted in the study

4. Hospital Pusrawi Sdn. Bhd.

a. Chief Executive Officer

b. Nursing manager

c. Assistant nursing managers

d. All employees who assisted in the study

\section{REFERENCES}

Abdullah, M. (2015). Actress Shahriza Mahmud is angry at the 'rude' treatment of hospital staff. Astro Awani. Retrieved from: https://www.astroawani.com/berita-hiburan/pelakon-shahriza-mahmud-berang-layanan-biadab-petugashospital-81326

Al-Kandari, F.H. and Lew, I. (2005). Kuwaiti high school students' perceptions of nursing as a profession: Implications for nursing education and practice. Journal of Nursing Education, 44(12), pp 533-540.

Başkale, H. and Serçekuş, P. (2015). Nursing as career choice: Perceptions of Turkish nursing students. Contemporary Nurse, 51(1), pp 5-15.

Berita Harian. (1957a). 'Jangan malu jururawat di-beritahu (Do not be ashamed - nurses told)', Berita Harian, 23 September, p. 2.

Berita Harian. (1957b). 'Gadis ini ta' suka merawat (Young women are uninterested in nursing)', Berita Harian, 18 December, p. 5.

Berita Harian. (1957c), 'Sebab2 kurang Jururawat (Reasons for insufficient nurses)', Berita Harian, 25 December, p. 7.

Berita Harian. (1957d). 'Belajar ilmu jururawat (Learning nursing)', Berita Harian, 29 August, p. 3.

Berita Harian. (1958a). 'Perkara ugama (Religious matters)', Berita Harian, 7 October, p. 7.

Berita Harian. (1958b). 'Jururawat yg berdansa ibu bapa naik radang (Nurses' dance angers parents)', Berita Harian, 24 
June, p. 6.

Berita Harian. (1959a). 'Mogok 'kerja hina' - Kementerian na' putuskan (Strike for 'low work' - Ministry to decide)', Berita Harian, 31 March, p. 5.

Berita Harian. (1959b). 'Jururawat di-tikam orang sakit(Nurse stabbed by patient)', Berita Harian, 23 September, p. 1.

Berita Harian. (1959c). ‘Orang sakit pukul nurse (A patient hit a nurse)', Berita Harian, 2 May, p. 5.

Berita Harian. (1959d), 'J-rawat: bedzakan kasar dan tegas (Nurse: differentiate rudeness and firmness)', Berita Harian, 26 September, p. 10.

Berita Harian. (1960a). 'Peluang menjadi juru-rawat (Opportunity to become nurses)', Berita Harian, 31 March, p. 5.

Berita Harian. (1960b). ‘Australia beri 60 biasiswa jururawat', Berita Harian, 5 March, p. 5.

Berita Harian. (1961a), "Jururawat yg tidak melayan orang sakit harus di-awas (Nurses who do not serve patients should be observed)", Berita Harian, 28 April, p. 1.

Berita Harian. (1961b). 'Layanan maseh ta' memuaskan (Soft skill still unsatisfactory)', Berita Harian, 4 September, p. 4.

Berita Harian. (1962a). Di-hukum kerana chium jururawat di-hospital (punished for kissing nurse at hospital)', Berita Harian, 19 December, p. 5.

Berita Harian. (1962b). 'Sikap kasar jururawat_UMNO akan bertindak (Rudeness of nurses, UMNO will take action)', Berita Harian, 14 July, p. 8.

Berita Harian. (1962c). 'Kesal sikap jururawat (Regret for the nurses' attitudes)', Berita Harian, 4 June, p. 4.

Berita Harian. (1963a). 'Menyediakan ranchangan kesehatan: beberapa kemudahan untok ra'ayat di-seluroh kampong (Preparing the healthcare plan: a few facilities for the people in villages)', Berita Harian, 4 December, p. 6.

Berita Harian. (1963b). ‘Temasha (Festival)', Berita Harian, 13 January, p. 10.

Berita Harian. (1964a). ‘Kenapa tidak ramai yang mau jadi jururawat?', Berita Harian, 15 September, p. 6.

Berita Harian. (1964b), "Jururawat bersuami luar nikah di-hukum (Nurse with illicit relationship punished)", Berita Harian, 17 September, p. 5.

Berita Harian. (1965a). 'Khir kesal tudohan terhadap jururawat (Khir dissappointed with the allegations towards nurses)', Berita Harian, 26 September, p. 1.

Berita Harian. (1965b). 'Pakaian jururawat menjolok mata, masharakat kesal (Nurse uniform too revealing, the society is dissappointed)', Berita Harian, 1 February, p. 6.

Berita Harian. (1965c). 'Kursus utk jururawat, kakitangan kerajaan (Course for nurses, civil servants)', Berita Harian, 23 April, p. 6.

Berita Harian. (1966a). '324 saja dari 3,000 jururawat ia-lah Melayu (Only 324 of 3,000 nurses are Malays)', Berita Harian, 12 November, p. 5.

Berita Harian. (1966b). 'Kami jadi mangsa’ 200 mengadu ('We are victims' 200 complained)’, Berita Harian, 25 July, p. 1.

Berita Harian. (1966c). 'Asrama bidan dan jururawat: surat kapada menteri (Midwives and nurses dorm: letter to the minister)', Berita Harian, 5 April, p. 2.

Berita Harian. (1966d). ‘Hubongan mesra di-hospital (Friendly service at hospital)', Berita Harian, 27 November, p. 4.

Berita Harian. (1967a). 'Gerakan mesra telah berjaya (Friendly Movement was successful)', Berita Harian, 27 September, p. 3 .

Berita Harian. (1967b). 'Gerakan Mesra' di-lancharkan('Friendly Movement'launched)', Berita Harian, 6 June, p. 2. 
Berita Harian. (1968a). 'Jururawat2 di-seru sedia berkhidmat di-mana saja (Nurses are encourage to be ready to serve where ever they are posted)', Berita Harian, 21 January, p. 5.

Berita Harian. (1968b). 'Kesah suami 'berzina' di-bawa dalam mahkamah (The case of husband commiting adultery taken to court)', Berita Harian, 25 May, p. 10.

Berita Harian. (1968c). 'Gerakan Mesra' untok timbulkan harmoni ('Friendly Movement' to improve harmony)', Berita Harian, 22 September, p. 6.

Berita Harian. (1968d). 'Mesti pandai ambil hati orang2 kampong, kata Menteri Bahaman (Must know how to win the villagers heart, says Minister Bahaman)', Berita Harian, 9 January, p. 5.

Berita Harian. (1969). 'Ka-UK belajar jururawat (To UK for nursing training)', Berita Harian, 16 September, p. 2.

Berita Harian. (1970). 'J-rawat2 anjor tari menari(Nurses organise ball)', Berita Harian, 5 February, p. 3.

Chauke, M.E., Wal, D.V.D. and Botha, A. (2015). Using appreciative inquiry to transform student nurses' image of nursing, Curationis, 38(1).

Chong, M.C. (2007). 'Perception on nursing profession and course and academic performance', 7th Annual SEAAIR Conference Proceeding, South East Asian Association for Institutional Research and Assumption University, Thailand, Bangkok.

Dain, R. (2005). 'Jururawat kerjaya mulia', Utusan Online. Retrieved from: http://ww1.utusan.com.my/ utusan/info.asp? $\mathrm{y}=2005 \& \mathrm{dt}=0718 \& \mathrm{sec}=\mathrm{keluarga} \& \mathrm{pg}=\mathrm{ke} \_01$.htmHey hey

Day, R.A., Field, P.A., Campbell, I.E. \& Reutter, L. (1995). Students' evolving beliefs about nursing: from entry to graduation in a four-year baccalaureate programme. Nurse Education Today, 15(5), pp 357-364.

Roux, G. \& Halstead, J.A. (2017). Issues and Trends in Nursing: Practice, Policy and Leadership: Practice, Policy and Leadership, 2nd ed., Jones and Bartlett Publishers; Sudbury.

Eman, T., Cowman, S. and Edgar, A. (2012). A triangulation study: Bahraini nursing students' perceptions of nursing as a career. Journal of Nursing Education and Practice, 2(3), pp 81-92.

Finkelman, A. \& Kenner, C. (2010). 'The Image of Nursing: What It Is and How It Needs to Change' in Professional Nursing Concepts: Competencies for Quality Leadership. Retrieved from: http://samples.jbpub.com/ 9781449649029/46066_CH03_6031.pdf

Geiger-brown, J., Trinkoff, A.M., Nielsen, K., Lirtmunlikaporn, S., Brady, B. \& Vasquez, E.I. (2004). Nurses' perception of their work environment, health, and well-being: A qualitative perspective, AAOHNJournal, 52(1), pp $16-22$.

Girvin, J., Jackson, D. \& Hutchinson, M. (2016). Contemporary public perceptions of nursing: a systematic review and narrative synthesis of the international research evidence. Journal of Nursing Management, 24(8), pp 994-1006.

Grainger, P., Bolan, C., Studies, N., Hall, S., Rd, F., John, S. \& Aa, C. (2006). Perceptions of nursing as a career choice of students in the Baccalaureate nursing program. Nurse Education Today, 1, pp 38-44.

Gunawan, J., Aungsuroch, Y., Sukarna, A., Nazliansyah \& Fendi, F. (2018). The Effects of Inhalation Aromatherapy. Nursing and Midwifery Studies, 8(1), pp 45-49.

Hallam, J. (1998). From angels to handmaidens: Changing constructions of nursing's public image in post-war Britain. Nursing Inquiry, 5(1).

Hasli, F.A. (2014). 'Trending 'tikar terbang', syirik dan memalukan ('Flying carpet' trending, shirk and embarrassing)', Sinar Harian, 13 March. Retrieved from: http://www.sinarharian.com.my/mobile/sukan/ trending-tikar-terbang-syirik-dan-memalukan-1.259669

Hemsley-brown, J. \& Foskett, N.H. (1999). Career desirability: young people's perceptions of nursing as a career. Journal of Advanced Nursing, 29(6), pp 1342-1350. 
Hudson, G.R. (1993). Empathy and technology in the coronary care unit. Intensive and Critical Care Nursing, 9(1), pp 55-61.

Jinks, A.M. \& Bradley, E. (2004). Angel, handmaiden, battleaxe or whore? A study which examines changes in newly recruited student nurses' attitudes to gender and nursing stereotypes. Nurse Education Today, 24(2), pp 121-127.

Kalisch, B.J. \& Kalisch, P.A. (1983). Anatomy of the image of the nurse: dissonant and ideal models. American Nurses Association Publications, G-161, pp 3-23.

Kalisch, B.J., Begeny, S. \& Neumann, S. (2007). The image of the nurse on the internet, Nursing Outlook, 55(4), pp $182-188$.

Kamaruzaman, N.H. (2016). 'Tarikan gaji lumayan (lure of high pay)', My Metro, 19 August. Retrieved from: https://www.hmetro.com.my/node/160340

Kelly, J., Fealy, G.M. \& Watson, R. (2012). The image of you: Constructing nursing identities in YouTube. Journal of Advanced Nursing, 68(8), pp 1804-1813.

Koo, M. \& Lin, S.C. (2016). The image of nursing: a glimpse of the internet. Japan Journal of Nursing Science, 13(4), pp 496-501.

Manninen, E. (1998). Changes in nursing students' perceptions of nursing as they progress through their education. Journal of Advanced Nursing, 27(2), pp 390-398.

Mariam. (1959). Kebanyakan anak ingin jadi guru yang berjasa (Many kids want to be teachers). Berita Harian, 9 December, p 6.

Mebrouk, J. (2008). Perception of nursing care: views of Saudi Arabian female nurses. Contemporary Nurse, 28(1-2), pp 149-161.

Milisen, K., De Busser, T., Kayaert, A., Abraham, I. \& Dierckx de Casterlé, B. (2010). The evolving professional nursing self-image of students in baccalaureate programs: a cross-sectional survey. International Journal of Nursing Studies, 47(6), pp 688-698.

Mohamad, M. (1970). The Malay Dilemma, Donald Moore for Asia Pacific Press, Singapore.

Moore, A. (2001). Not for love nor money. Nursing Standard, 16(12), pp 14-15.

mStar Online. (2010a). 'Missy' dulu, 'Misi' sekarang (Missy then, Misi now)', MStar Online, 10 May. Retrieved from: http://www.mstar.com.my/lain-lain/rencana/2010/05/10/missy-dulu-misi-sekarang/

mStar Online. (2010b). 'Malaysia perlu lebih ramai tenaga jururawat mahir (Malaysia needs more skilled nurses)', MStar Online, 14 January. Retrieved from: http://www.mstar.com.my/berita/berita-semasa/2010/01/14/malaysiaperlu-lebih-ramai-tenaga-jururawat-mahir/

mStar Online. (2016). 'Nisbah jururawat dan penduduk Malaysia kini 1:297 (Current nurse to population ratio is 1:297)', MStar Online, 11 May. Retrieved from: http://www.mstar.com.my/berita/berita-semasa/2016/05/11/ nisbah-jururawat-penduduk-malaysia/.

Patidar, A.B., Kaur, J., Sharma, S.K. and Sharma, N. (2011). Future nurses' perception towards profession and carrier plans: A cross sectional survey in state Punjab. Nursing and Midwifery Research Journal, 7(4), pp 175-185.

Phillips, P. (1993). Adeconstruction of caring. Journal of Advanced Nursing, 18(10), pp 1554-1558.

Ratnamala. (1963). Lebeh ramai patut turut berbakti (More should provide service), Berita Harian, p 6.

Robinson, J. (1989). Current Issues in Nursing, Springer; Boston.

Stanley, D.J. (2008). Celluloid angels: A research study of nurses in feature films 1900-2007. Journal of Advanced Nursing, 64(1), pp 84-95. 
Sulaiman, N.A. (2019). 'Pengorbanan jururawat bak 'hero' (Nurses sacrifice like heros)', Berita Harian Online, 18 June, Retrieved from: https://www.bharian.com.my/berita/nasional/2019/06/575446/pengorbanan-jururawat-bak-hero

Tawash, E.A. \& Cowman, S. (2015). Bahraini nursing students' attitudes: from student to nurse - A longitudinal research study. Journal of Nursing Education and Practice, 5(12), pp 79-87.

The Star. (2005). 'Government wants more non-Malay nurses', The Star, 24 August. Retrieved from: https://www.thestar.com.my/news/nation/2005/08/24/government-wants-more-nonmalay-nurses

Utusan Online. (2018). 'Lambakan doktor, jururawat ditangani (Oversupply of doctors and nurses being dealt)', Utusan Online, 10 June. Retrieved from: http://www.utusan.com.my/berita/nasional/lambakan-doktor-jururawat-ditangani1.688864

While, A. \& Blackman, C. (1998). Reflections on nursing as a career choice. Journal of Nursing Management, 6(4), pp 231-237.

Yazid, Z. (2010). 'Jururawat kerjaya mulia', Utusan Online, 3 February. Retrieved from: http://ww1.utusan. com.my/utusan/info.asp? $\mathrm{y}=2010 \& \mathrm{dt}=0203 \& \mathrm{sec}=$ Rencana\&pg=re_11.htm. 